Journal of Business and Tourism

Volume 06 Number 01

January - June, 2020

\title{
Analysis of Various Factors Contributing To Police Corruption In Khyber Pakhtunkhwa
}

\author{
Rahman Hussain \\ Ph.D. Scholar, Department of Sociology \\ University of Peshawar \\ rahman334@hotmail.com
}

Dr. Habibullah Nawab

Lecturer in Sociology, Govt Post Graduate Jehanzeb College

Saidu Sharif Swat

habib_soc@yahoo.com

\section{Hazrat Bilal}

MA Sociology, Abdul Wali Khan University, Mardan

h.bilal555@yahoo.com

\section{Muhammad Ishaq}

Lecturer in sociology, Abdul Wali Khan University

isak700@gmail.com

\begin{abstract}
Around the world police institution has been established for ensuring peace, enforcing law and protecting life and property of public. Policeplays a vital role in controlling crimes in society and their services are considered as good, but police corruption has also been occurred throughout history and therefore it is by no means a new phenomenon. In Pakistan too police are perceived as corrupt and there exist various social, economic, political and structural causes of police corruption.The multiplicity of these causes and its aftermaths in delivery of justice require immense research in the field. Looking into the issue the current study was conducted in province of Khyber Pakhtunkhwa, Pakistan to know the opinion of in-service police about prevalence of corruption in police department of Khyber Pakhtunkhwa and the contributing factors which compel police personnel for corruption. Data was collected through structured questionnaires from in-service police, using purposive sampling techniques. The data collected from 150 respondents who were serving in police department.According to findings of the study $88.7 \%$ respondents opined that corruption prevails in police department of Khyber Pakhtunkhwa. The study identified low salaries, lack of accountability, recruitment through bribes, political patronage, corruption of senior officers, lack of public awareness and lack of resources as major causes of police corruption. To eliminate corruption from police department, the study suggestsstrict and unbiased accountability, increase in salaries, public awareness, discouraging political
\end{abstract}


interference, establishment of an independent commission for controlling corruption and strict disciplinary action against those involved in corruption.

Key Words: Police, Corruption, Causes, Lack of accountability.

\section{Introduction}

In democratic societies police is regarded as an important institution. It is a public institution established for crime detection, deterrence, maintaining rule of law and bringing to justice the law breakers. The institution of police is responsible for protecting general masses, ensuring peace and thereby providing peaceful environment to all citizens of the state. This institution is a mean through which people may live safely in their home. This dream come true only, when the police are professional, well trained, well equipped and fairly perform their duty (Cheema, 2011). A positive public- police relationship is very important which brings mutual trust and also give confidence to police (Srivastava, 1999). While police corruption undermines public trust on the institution and widens the gap between the public and police (Klockars, Ivkovic\&Haberfeld, 2004).

Police corruption is a global problemand both developed and developing countries are suffering from this menace (Ashimala, 2014). It also prevails in United States of America (John \& Linda, 2006), but the nature, extent, methodsand intensity of corruption vary from country to country.In Pakistan allegations of police corruption is a well know phenomenon (Ullah, Zia, Akhunzada\& Imran, 2015). In ourcountry police corruption is more visible and the degree of its occurrence is also high. Every rank of police is corrupt (Pakistan Country Reports on Human Rights Practices, 2011). Similarly, people perceive Khyber Pakhtunkhwa police as dishonest and corrupt (Farhat ullah et.al, 2015). According to Abro (2009) police corruption affects performance of police to control crimes and also damage the reputation of police department. Because of corruption police are more interested in personal benefits rather than to serve the public. Several factors are responsible due to which police indulge in corrupt practices, such as lack of police integrity, police culture and loopholesavailable for corruption (Grant \& Kevin, 2002; Newburn, 1999).

Ivkovic (2005) pointed out that in past low moral values of police was considered as one of the main reason of police corruption. But latter it was proved by many researchers as well various commissions that were formed to investigate causes of police corruption, that along with low moral values there are numerous other reasons that furnish favorable base for police corruption which include culture of police department, limited resources and political interference.Svensson (2005) also found that political influence allows police to take bribes from the citizens. In Khyber Pakhtunkhwa, recruitmentin police department is done on the bases of political influence and the improper hiring paves the way for corruption in the institution (Farhat ullah et.al: 2015). Political 
interferenceundermines the professional obligations of police and ultimately breeds mistrust in the community at large (Clarke, 2017).

\section{Literature Review}

Corruption is a Latin word which means to pollute or spoil or abuse. It is the abuse of public resources and misuse authority for personal benefits (Transparency International, 2012). Anyact of public officials that surpass the limit of vested power and authority can be referred as corruption (Javid, 2010).Corruption is the"offering, giving, receiving, and soliciting, directly or indirectly of anything of value to influence improperly the actions of another party" (David \& Sharma, 2010).

Police corruption refers to the act of an officer that is against of his duty and is done for personal benefits or promise for such benefits (Punch: 2009). Corruption is the exploitation of position which leads to the break of trust which the public have on the police. Police and police corruption go side by side and when there are police there will be corruption (Punch: 2009). This is a worldwide problem which exists globally in various forms. In developing countries police corruption is a matter of routine and everyone become victims who deal with the police (Farhatulla et.al: 2015).

The print and electronic media regularly highlights the incidents of police corruption in Pakistan. It is so prevalent and visiblethat police can be seen on roads taking bribes from drivers. Because of corruption reputation of Police in Pakistan is poor and they are avoided by the public to get their services (Farhatullah et.al: 2015). In Pakistan public perceive police as corrupt and dishonest. According to Transparency International, "Police remains the most corrupt sector according to the perceptions of Pakistanis (Transparency International: 2010).

Various factors are responsible that compel police for corruption. Among them the culture background is the most important factor. In 1861 colonial police was established after the war of independence as ruler force; with the aim to frighten the public. As subjugationof Indians was the prime objective, which was successfully achieved through the police.Their purpose was not to serve the public and thus they were brutal.The culture of Pakistani police is rooted in colonial where the police used to serve higher class and giving no attention to the general public (Khan, Naz, \&Sanaullah, 2017). This has been regarded as the prime reason that police in Pakistan have not been regarded as civil servants but representing upper class of society (Ayub, 2009). They are not independent and impartial and their work is influenced by the politicians (Arain, 2014) and they have been used for political purpose against their opponents (Daily Dawn, 2012).

Similar studies have found that sufficient funds and resources are not provided to the police, and the SHOs are supposed to manage the expenses from own pockets which compels them for corruption (Javed, 2015).Lack of accountability in police department is also a cause of corruption which motivates police officials to adopt corrupt practices. The same pointed out by human right commission of Pakistan, which statesthat functional mechanisms are very limited to hold the police accountable for their wrong doings (Jamal, 2011).Similarly, when low salaries are paid to civil servants, itcompels them for 
corruption. Rose-Ackerman also stated that "Corruption is adopted a strategy for survival when civil servants are not handsomely paid (Ivkovic, 2005). Other reasons that compel police personnel towards corruption include police culture (Cockcroft, 2013), Political patronage (Perito\&parvez, 2014) personal greed and wish to become rich through improper ways and means.

\section{Study Rationale}

Corruption is a scorching issue of Pakistan. Print and electronic media highlights that no public sector is immune from the cancer of corruption. Generally, people perceive police as most corrupt department which is also ranked several times by transparency international as the most corrupt department of Pakistan. The institution has been established with prime responsibility to protect citizens' rights, but because of widespread corruption police are unable to serve the general public. Corruption has vanished personal integrity of police and has resulted in defamationof police department. Because of corruption the institution is not respected by the general public and has lowered public confidence and trustand people consider the institution as worthless.

At large public criticize police for their inefficiency, corrupt practices and politicization. It has resulted in mistrust among the masses and a common perception is that, to get the services of police, they will have to be bribed. For ensuring peace and order in the society police corruption must be eliminated from the department. Police are involved in corrupt practices because of various reasons. This study was conducted to know from the police themselvesabout corruption in police department of Khyber Pakhtunkhwa, its causative factors and to give recommendations for addressing

\section{Research Methodology}

The study was conducted to know about corruption in police department of Khyber Pakhtunkhwa and its contributing factors. The primary data was collected from in-service police personnel. The data was collected from 150in-service police including constables, Assistant sub Inspectors (ASIs), Sub Inspectors (SIs), Deputy Superintendent of Police (DSPs) and Superintendent of Police (SPs). The data was collected through close ended questionnaires and face to face interviews were conducted with the respondents. The collected information was analyzed through SPSS, generated simple frequencies and the data presented in the form of descriptive statistics.

\section{Study Results}

\section{Demographic Information}

The table 1highlightsrespondents' demographic information, their age, education and length of service in police department. All these are very essential indicators which shows about the maturity and knowledge of the respondents regarding a specific problem selected for research. Out of total $150(100 \%), 29(19.3 \%)$ were in the age group 20-30 years, 59(39.3\%) were in the age group 31-40 years, 48(32\%) were 41-50 years and $14(9.3 \%)$ were in the age group 51-60 years. Similarly, out of total $150(100 \%)$ respondents $1(0.7 \%)$ respondent was uneducated, $6(4 \%)$ were primary passed, $36(24 \%)$ were matriculate, $42(28 \%)$ had intermediate level education, 36(24\%) were graduates and 
$29(19.3 \%)$ had master level education. Out of total respondents $89(59.3 \%)$ were serving on the rank below sub inspector, 24(16\%) on the rank of sub inspector, 16(10.6\%) as inspectors, $11(7.3 \%)$ on the rank of DSP and 5(3.3\%) each were serving on the rank of ASP, SP and above ranks. As for as the family size was concerned, 9(6\%) respondents reported their family size of 2-3 persons, 27(18\%) had 4-5 members in the family, maximum number of respondents $71(47.3 \%$ ) reported family size of 6-7 persons, the next highest number was of $37(24.6 \%)$ who had a family size of up to 8-9 members and the least number of $6(4 \%)$ had a family size of more than ten persons. On the average the family size was 6.5 .

Further29(19.3\%)respondents had a service length of up to five years in Khyber Pakhtunkhwa police department, 39(26\%) respondents were in service from 6-10 years, $21(14 \%)$ respondents were in service from 11-15 years, and the same number of respondents $21(14 \%)$ had service length of up to $16-20$ years. $25(16.6 \%)$ respondents were in service from last 21-25 years and 15(10\%) were on service in police department from more than 26 years.

\section{Findings of the Study (Results and Discussion)}

Table 2describesthe opinionsof respondents they sharedabout prevalance of corruption in police department of Khyber Pakhtunkhwa and various factors that compel police towards corruption. According to the study findings out of 150 (100\%), 133(88.7\%) answered that corruption prevails in police department of Khyber Pakhtunkhwa whereas only $17(11.3 \%)$ were disagree with the statement. Like stated by Sarwar (2014) that corruption is a main issuewhich suffer the police mostly in third world countries. According to Carl B. Klockars et. all, (2004) police do not work until they are bribed and to register a criminal case with the police a victim has to pay bribes and same for starting investigation. The general public also perceive police of Khyber Pakhtunkhwa as corrupt. According to a study titled "Perception about police corruption in Khyber Pakhtunkhwa, Pakistan", 90\% respondents were of the view that corruption is done by Police of Khyber Pakhtunkhwa (Farhat ullah et.al, 2015). It is since of debasement that when the citizens see the police and their officers anyplace, they conceive them a untrustworthy, and image of fear and fixing (Chadhar, 2006). Similarly, majority of the respondents i.e $108(72 \%)$ opined that low salaries paid to police compel them for corruption, whereas $29(19.3 \%)$ were against the statement and the remaining 13(8.6\%) had no idea. Rose- Ackerman (1999) also pointed out that "Corruption is adopted a strategy for survival when civil servants are not handsomely paid". Beside this 106(70.6\%) respondents were of the view that lack of accountability encourages police personnel for corruption whereas $28(18.6 \%)$ were not agree and the same number $28(18.6 \%)$ had no knowledge about it. It was also argued by Warraich (2004) that lack of accountability in police department leads to corruption.Further 101(67.3\%) answered that political patronage encourages police officials for corruption, while 35(23.3\%) were disagree and $14(9.3 \%)$ having no idea. Svensson (2005) also states that political influence furnish ground for police to take bribes from the citizens.Perito and Parvez (2014) stated that the police are promoted as 
well transferred on the saying of influential politicians. Similarly, 101 (67.3\%) opined that police corruption is because of lack of awareness among the public whereas $28(18.6 \%)$ were not agree with the statement and 21(14\%) did not know about it. It was also highlighted by the findings of a report submitted to subcommittee on African affairs in US senate, that unawareness of the public and their tolerant attitudes enhance the level of corruption (United States General Accounting Office, 2004). In addition, 89(59.3\%) were agreed that police corruption is because of lack of transparency in the process of police recruitment, but55 (36.6\%) were against the statement and remaining 6(4\%) did not know about it. As stated by Roebuck \& Barker (1974), corruption is done in police recruitment. Further, 97(64.6\%) responded that lack of resources is a cause of police corruption, but $25(16.6 \%)$ were disagree and $27(18 \%)$ having no idea about it. This was also highlighted by Azeem (2015) that police don't have funds for investigation, fuel for operation and funds for medical, chemical and scientific tests etc, which compel them for corruption. Beside this, 87(58\%) were agree that corruption of senior police officers motivate junior police officials towards corruption whereas 32(21.3\%) were not agree with the statement and 31(20.6\%) had no knowledge about this cause. Holmes (2010) also argued that "one of the most important cause of corruption among the lower cadre of police is poor role-modeling from their seniors... Beside this if police corruption is to be eradicated it is essential that senior officers should set a good example".

\section{Conclusion}

The findings of the study highlight that corruption prevails in police department of Khyber Pakhtunkhwa. It was observed from the views of respondents that corruption has damaged the reputation of police department and to restore the actual image of police department, the problem must be addressed. From the view point of respondent's, various loopholes exist due to which the level of corruption is high. Among them the major cause of corruption in police is low salaries which are paid to them. Similarly, lack of accountability and political influence also has created space for corruption due to which the police suffer from this menace. Further unfair recruitment, lack of public awareness, corruption of senior officers and lack of sufficient funds for investigation and police operation also compel police officials for corruption. To restore the reputation of police the problem of corruption must be tackled and positive steps should be taken for addressing the problem of corruption. There should be strict and unbiased accountability, salaries should be increased especially for the lower ranks, political interference in the work of police should be discouraged and recruitment should be done on merit. Beside this public awareness should be increased and an independent commission for controlling

corruption should be established and strict disciplinary action should be taken against those found in corruption.

\section{References}

Ackerman, R.S. (1999). Corruption and government: Causes, Consequences, and Reforms (Cambridge University Press) 
Arain, S.M. (2014). Women Police Unfurled: Perspective, Status and Prospective" (Hyderabad: A House ofKnowledge).

Ashimala, J.H. (2014). Problem of Policing in Africa. Thesis submitted to University Nairobi, Institute of Diplomacy and International Studies.

Azeem, M. (2015). Crime diary: Lack of funds breeds corruption in police. The Daily Dawn.

Chadhar, A.K. (2006). Jurm Nishan Chorta Hi. (Lahore: Jahangir Printers). P 67.

Cheema, U. (2011). Who Control the Police, Centre or Provinces? The Daily News 11

September.

Clarke, D. (Host). (2017). Why Communities need their Police to be free from Political Influence. Radio program (London: BBC).

Cockcroft, T. (2013). Police culture: Themes and concepts (London: Routledge) p22 CfWaddington, P. A. J. (2008) "Police Culture. Dictionary of Policing. Devon" Willan publishing.

Farhat, U., Akhunzada, Z.U \& Sajid, I.A. (2015). Crossing the line: Perception about police corruption in Khyber Pakhtunkhwa, Pakistan. Pakistan Journal of Criminology, Vol 7, No 4. Oct 2015 Pp 103-115.

Holmes, L. (2010). Australian Police Corruption in Comparative Perspective. Australian Political Studies Association 58th Annual Conference, University of Melbourne, 26-29 September 2010.

Ivkovic, S. K. (2005). Fallen Blue Knights: Controlling Police Corruption. (New York: OXFORD University Press).

Jamal, A. (2011). Revisiting police laws Lahore: Maktaba Jadeed press A report of human right commission of Pakistan.

Javid, U. (2010). Corruption and its Deep Impact on Good Governance in Pakistan Pakistan economic and Social Review, 48(1), 123-134 (summer 2010)

John, D.S. \& Linda, F.S. (2012). An introduction to Policing (6th edition) P 218

Khan, A.J. (2015). Inadequate official funds compel SHOs to indulge in corruption. Published in Daily News.

Khan, M. A., Naz, A., Khan, W., Khan, N. \& Sanaullah (2017). Analysis of the Communal Attitudes Concerning Police System and Policing in Pakistan. Journal of Social Sciences and Humanity Studies, P11.

Klockars,C.B, Ivkovic, S.K \&Haberfeld, M.R (2004) "The Contours of Police Integrity" (London: Sage Publications)

Newburn, T. (1999). Understanding and Preventing Police Corruption: Lessons from the Literature. No 2, PP 5-6.

Perito, R. \& Parvez, T. (2014) A counter terrorism role for Pakistani's police stations. Published by United States Institute of Peace p2.

Punch, M. (2009). Police Corruption: Deviance, Accountability and Reform in Policing. New York: Routledge. 
Quah, J.S.T. (2006). Preventing Police Corruption in Singapore: The Role of Recruitment, Training and Socialization. in The Asia Pacific Journal of Public Administration Vol. 28, NO. 1 (JUNE 2006): 59-75.

Sarwar, N. (2014). What Youth think about Corruption in Pakistan". accessed at http://www.youthtimes.com.pk/youth-think-corruption-pakistannazneen-sarwar/ retrieved on June 2, 2019.

Shoro, S. (2017). Honor Killing in The Second Decade of the 21st Century" (Cambridge: Cambridge Scholars Publishing) P 177.

Srivastava, A (1999). Role of Police in a Changing Society" (New Delhi: A.P.H Publishing Corporation) P 242.

Svensson, J. (2005). Eight Questions about Corruption. Journal of Economics Perspectives. 19(3), 19-42

Svensson, J. (2005). Eight Questions about Corruption. Journal of Economics Perspectives. 19(3), 19-42

The Daily Dawn, September 19, 2012.

Transparency International-Pakistan Report (2010). National Corruption Perception Survey, P15.

United States General Accounting Office (2004). Foreign assistance U.S. anticorruption programs in sub Saharan Africa will require time and commitment. P 11.

West, D.J \& Green, R (2002) "Sociolegal Control of Homosexuality: A Multi-Nation Comparison (New York: Kluwer Academic Publishers)

www.en.wikipedia.org/wiki/Police_corruption.

www.nayyab.wordpress.com/2010/03/05/pakistani-police-shame-for-society/ retrieved on Apr 15, 2016

\section{Annex 1}

Table I: Respondents Demographic Information

\begin{tabular}{|l|l|l|}
\hline Respondents Age & No of respondents & Percentage \\
\hline $20-30$ years & 29 & $19.3 \%$ \\
\hline $31-40$ years & 59 & $39.3 \%$ \\
\hline 41-50 years & 48 & $32 \%$ \\
\hline 51-60 years & 14 & $9.3 \%$ \\
\hline Total & $\mathbf{1 5 0}$ & $\mathbf{1 0 0 \%}$ \\
\hline Education of Respondents & Frequency & Percentage \\
\hline Uneducated & 1 & $0.7 \%$ \\
\hline Primary passed & 6 & $4 \%$ \\
\hline Matriculate & 36 & $24 \%$ \\
\hline Intermediate pass & 42 & $28 \%$ \\
\hline Graduates & 36 & $24 \%$ \\
\hline Master & 29 & $19.3 \%$ \\
\hline & &
\end{tabular}




\begin{tabular}{|l|l|l|}
\hline Total & $\mathbf{1 5 0}$ & $\mathbf{1 0 0 \%}$ \\
\hline Rank of Respondents & Frequency & Percentage \\
\hline $\begin{array}{l}\text { Below Assistant sub- } \\
\text { inspector }\end{array}$ & 89 & $59.3 \%$ \\
\hline Sub inspector & 24 & \\
\hline Inspector & 16 & $16 \%$ \\
\hline DSP & 11 & $10.6 \%$ \\
\hline ASP & 5 & $7.3 \%$ \\
\hline ASP \& Above & 5 & $3.3 \%$ \\
\hline Total & $\mathbf{1 5 0}$ & $3.3 \%$ \\
\hline Family Size & Frequency & $\mathbf{1 0 0 \%}$ \\
\hline 2-3 persons & 9 & Percentage \\
\hline 4-5 Persons & 27 & $6 \%$ \\
\hline 6-7 Persons & 71 & $18 \%$ \\
\hline 8-9 persons & 37 & $47.3 \%$ \\
\hline More than 10 persons & 6 & $24.6 \%$ \\
\hline Total & $\mathbf{1 5 0}$ & $4 \%$ \\
\hline $\begin{array}{l}\text { Police Experience/Length } \\
\text { of service }\end{array}$ & Frequency & $\mathbf{1 0 0 \%}$ \\
\hline 1-5 years & 29 & Percentage \\
\hline 6-10 years & 39 & $19.3 \%$ \\
\hline 11-15 years & 21 & $26 \%$ \\
\hline 16-20 years & 21 & $14 \%$ \\
\hline 21-25 years & 25 & $14 \%$ \\
\hline 26 years and above & 15 & $16.6 \%$ \\
\hline Total & $\mathbf{1 5 0}$ & $10 \%$ \\
\hline & & $\mathbf{1 0 0 \%}$ \\
\hline
\end{tabular}

Annex II

Table II: Respondents Perceptions about police corruption and its causes

\begin{tabular}{|c|l|c|c|c|}
\hline S\# & \multicolumn{1}{|c|}{ Statement } & Agree & Disagree & $\begin{array}{c}\text { Don't } \\
\text { Know }\end{array}$ \\
\hline 1 & $\begin{array}{l}\text { Do you think corruption prevails } \\
\text { in KP police Department? }\end{array}$ & $88.7 \%$ & $11.3 \%$ & - \\
\hline 2 & $\begin{array}{l}\text { Do you think that low salaries of } \\
\text { police compel them for } \\
\text { corruption? }\end{array}$ & $72 \%$ & $19.3 \%$ & $8.6 \%$ \\
\hline 3 & $\begin{array}{l}\text { Is it true that lack of } \\
\text { accountability increase corruption } \\
\text { in police? }\end{array}$ & $70.6 \%$ & $18.6 \%$ & $18.6 \%$ \\
\hline 4 & $\begin{array}{l}\text { Is recruitment through bribes } \\
\text { cause corruption in police? }\end{array}$ & $59.3 \%$ & $36.6 \%$ & $4 \%$ \\
\hline
\end{tabular}




\begin{tabular}{|c|l|c|c|c|}
\hline 5 & $\begin{array}{l}\text { Does the corruption of seniors } \\
\text { motivate junior for corruption? }\end{array}$ & $58 \%$ & $21.3 \%$ & $20.6 \%$ \\
\hline 6 & $\begin{array}{l}\text { Is lack of awareness among } \\
\text { citizens is a cause of corruption } \\
\text { amongst police? }\end{array}$ & $67.3 \%$ & $18.6 \%$ & $14 \%$ \\
\hline 7 & $\begin{array}{l}\text { Does political interference } \\
\text { compel police for corruption? }\end{array}$ & $67.3 \%$ & $23.3 \%$ & $9.3 \%$ \\
\hline 8 & $\begin{array}{l}\text { Does dearth of resources compel } \\
\text { police for corruption? }\end{array}$ & $64.6 \%$ & $16.6 \%$ & $18 \%$ \\
\hline
\end{tabular}

